\title{
En sammenlignende undersøgelse af praktikforløb og færdighedstræning i tre videregående uddannelser
}

Anne Mette Mørcke, Center for Medicinsk Uddannelse, Aarhus Universitet.

Kristian Raun Thomsen, Sektion for Idræt, Aarhus Universitet.

Jette Henriksen, Den Sundhedsfaglige Højskole, VIA University College.

Ole Lund, Center for Medicinsk Uddannelse, Aarhus Universitet.

Mette Krogh Christensen, Center for Medicinsk Uddannelse, Aarhus Universitet.

\section{Reviewet artikel}

Praktikforløb i videregående uddannelser er blevet et politisk indsatsområde, og der er i sundhedsuddannelserne også et internationalt forskningsfokus på emnet. I denne artikel vil vi beskrive og sammenligne rammerne for praktikforløb og færdighedstræning på idræts-, læge- og sygeplejerskeuddannelsen. Artiklen tager afsæt i Heggens skelnen mellem begreberne professionsidentitet og professionel identitet. Den studerendes opfattelse af sig selv som professionsudøver må ud fra dette afsæt udvikles via tilegnelse af både en særlig videnskabelig funderet teoretisk viden, særlig praktisk ekspertise, samt en sarlig etisk og social forpligtelse til at arbejde for medborgernes bedste. I den konkrete sammenligning af idræts-, læge- og sygeplejerskeuddannelserne konkluderes, at både fxrdighedstræning og praktik vægtes højt, men at både omfang, struktur, placering og læringsmål varierer betydeligt. Det må have væsensforskellige konsekvenser for de studerendes tilegnelse af viden, fardigheder og holdninger og dermed for deres professionelle identitetsudvikling. Vi kan ikke afgøre om professionsidentitetsforståelsen er årsag eller virkning, men der ser ud til at være et samspil mellem uddannelsernes undervisningsformer og professionsidentitet.

\section{Introduktion}

Praktikforløb er blevet et politisk indsatsområde og daværende uddannelsesminister Morten Østergaard skrev i 2012, at alle studerende på videregående uddannelser skal have mulighed for meritgivende praktik som en del af deres uddannelse (Politiko, 2012). Vi vil gerne bidrage til diskussionen med et empiribaseret indblik i uddannelserne på sundhedsområdet, som traditionelt har den efterspurgte meritgivende praktik indbygget. 
Der er en rig forskning i praktik i læge- og sygeplejerskeuddannelserne (Teunissen \& Wilkinson, 2011). Man har konkluderet 1) at arbejdspladser som fx sygehuse åbner for et overvældende antal autentiske læringsaktiviteter, 2) at den arbejdspladsbaserede læring foregår som en forhandling i en triade med den lærende, vejlederen og patienten, hvilket på samme tid er værdifuldt og problematisk, og 3) at både læringsproces og læringsudbytte er stærke, men samtidig vanskelige at styre da fokus må lægges på patienten. Bemærk, at der endnu ikke kan gives klare evidensbaserede anbefalinger til praktikkens omfang, balancen mellem praktik og færdighedstræning eller de konkrete læringsmål for praktik.

Det ser dog ud til, at praktik er en vigtig arena for studerendes dybere forståelse af professionerne og øger de studerendes bevidsthed om deres identitet (Løvold, 1996). Van der Zwet et al. (2011) interviewede lægestuderende om deres læring under en praktikperiode i almen praksis. De konkluderede, at de studerende udviklede deres professionelle identitet ved learning-by-doing i en udviklingszone. Denne zone var påvirket af kontekstens forskellige rumlige, tidsmæssige, organisatoriske og personlige læringsstimuli, samt af en række emotionelle og relationelle aspekter. Ikke overraskende opfordrede man til yderligere forskning.

Det ser også ud til, at praktik har betydning for professionsudøvelsen. Bleakly \& Brennan (2011) konkluderede i en sammenlignende, retrospektiv spørgeskemaundersøgelse blandt nyuddannede læger i UK, at studerende fra universiteter med struktureret praktik i studieordningen fik den bedste overgang til arbejdslivet som yngre læge. Undersøgelsen rejste dog også en række spørgsmål om hvordan og hvorfor.

Bevæger man sig uden for læge- og sygeplejerskeuddannelserne til idræt og tilsvarende, så er færdighedstræning og praktik som en integreret del af uddannelsen et underbelyst forskningsfelt. Enkelte studier peger dog på samarbejdsrelationen mellem praktiksted og universitet som et kritisk omdrejningspunkt for idrætsstuderendes professionsorienterede udbytte af praktikken (Chambers \& Armour, 2011; Standal \& Moe, 2013).

Denne artikels begrebsdannelse er inspireret af Kåre Heggen, der skelner mellem begreberne professionsidentitet og professionel identitet (Heggen, 2008). Professionsidentitet er ifølge Heggen udtryk for en kollektiv identitet, der handler om en fælles forståelses- og referenceramme, en overordnet fælles bestræbelse, som ikke er specifikt handlingsforeskrivende. Nogle professioner har en stærk professionsidentitet, hvor den individuelle identitet må underlægge sig professionsidentiteten. Andre professionsidentiteter er mere uforpligtende eller svagere og dermed uden modsætningsforhold. 
Professionel identitet er ifølge Heggen en personlig identitetsdannelse, der har med den konkrete udøvelse af professionen at gøre. Professionel identitet kan forstås som en persons opfattelse af sig selv som professionsudøver; hvilke egenskaber, værdier, holdninger, etiske retningslinjer, færdigheder og kundskaber, der tilsammen konstituerer 'mig som en god professionsudøver'. Denne professionelle identitet udvikles konstant i mødet mellem personen og professionen. I denne forståelse udvikler sygeplejestuderende således langsomt over tre år deres identitet i mødet mellem værdier, erfaringer og det, de lærer under sygeplejestudiet. Et andet eksempel er idrætslæreres livsforløb og faglige identitetsdannelse, hvor idrætsudøvelse er et kontinuerligt element og bevægekroppen er fokus for oprigtighed, engagement og kompetence i relation til idrætslærerprofessionen (Christensen, 2001).

Ud fra denne idealforståelse af professionsidentitet og professionel identitet forventes en persons opfattelse af sig selv som professionsudøver at blive udviklet via 1) en særlig videnskabelig funderet teoretisk viden, 2) en særlig praktisk ekspertise, samt 3) en særlig etisk og social forpligtelse til at arbejde for medborgernes bedste (figur 1). Dette er en klassisk opdeling med rødder helt tilbage til Aristoteles.

Figur 1

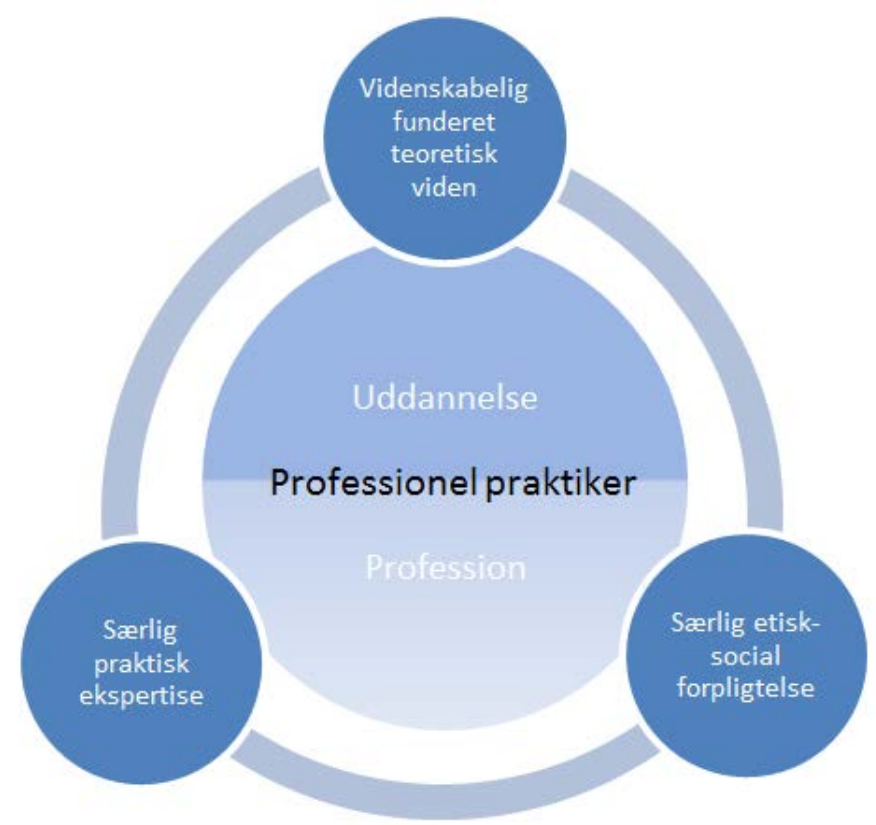

Figur 1: Den professionelle praktiker forventes at kunne sætte sin videnskabeligt funderede teoretiske viden og sin særlige praktiske ekspertise i spil med en særlig etisk-social forpligtelse. Denne forventning er forankret i professionen og forventes afspejlet i uddannelsen. 


\section{Formål}

Med denne artikel vil vi bidrage til det empiriske grundlag for de aktuelle vigtige diskussioner om praktik i videregående uddannelser ved at beskrive og sammenligne rammerne for praktikforløb og færdighedstræning på idræts-, læge- og sygeplejerskeuddannelsen.

\section{Metode}

Dette projekt er et tværsektorielt (Aarhus Universitet og VIA University College) og tværdisciplinært (idræts-, læge- og sygeplejerskeuddannelsen) multicasestudie. Vores antagelse er, at komparative casestudier bidrager til øget indsigt i de enkelte cases i studiet, fordi man i komparationen i højere grad kan undersøge partikulære træk i hver enkelt case i forhold til universelle træk. Det betyder konkret, at for at forstå betydningen af et bestemt uddannelseselement i én uddannelse kan det være frugtbart at spejle uddannelseselementet $i$ en anden uddannelse, der indeholder et tilsvarende uddannelseselement. Af hensyn til analysens omfang er antallet af cases begrænset til tre. Casene er udelukkende valgt fra sundhedsfaglige uddannelser, da disse har en lang tradition for betydelige praktikelementer og færdighedstræning (mere end to semestre), hvorfor man kan forvente, at disse elementer har en fast velintegreret plads i de respektive studieordninger. Alligevel ville vi forvente at finde betydelige forskelle. De tre cases er valgt fra uddannelsesinstitutioner i Region Midt, da dette gav os den bedste adgang til data.

Den anvendte metodik er desk research, der er relevant i afklarende, beskrivende studier som dette. Efterfølgende uddannelsesprojekter kan koste mange ressourcer, og det er derfor en grundlæggende god idé at undersøge, om andre har erfaringer, der kan bruges, inden et forsknings- eller udviklingsprojekt forsøges søsat på en uddannelsesinstitution. Der er ikke en egentlig lærebog i desk research-metode, men desk research anvendes hyppigt i uddannelseslitteraturen og sundhedsvidenskaberne på et meget bredt spektrum af felter og spørgsmål og publiceres i mange af de mere specialiserede tidsskrifter (Broek \& Hake, 2012; Kilminster et al., 2011; Skok \& Dolinsek, 2013). Begrænsningerne ved desk research er, at de indhentede informationer kan være forældede eller at de ønskede data ikke eksisterer. Derfor skal resultater af et desk research-projekt - som med alle andre metoder - altid vurderes for eventuelle begrænsninger i troværdighed og generaliserbarhed.

I dette studie indhentes for idræts-, læge- og sygeplejerskeuddannelsen informationer om meritgivende færdighedstræning og praktik samt informationer om, hvordan teoretisk viden, praktiske færdigheder og holdningsrelaterede kompetencer indgår og er beskrevet i studieordninger, kursusbeskrivelser og på hjemmesider. 


\section{Resultater}

\section{IDR $F T$}

Idrætsuddannelsens første tre semestre på Aarhus Universitet (AU) består af obligatoriske fag. Derefter kan den studerende vælge, i hvilken retning uddannelsen skal styres. Der er tre spor: 1) det biologiske, 2) det humanistisk-samfundsvidenskabelige og 3) det praktisk-teoretiske. Det viste spor er det humanistisksamfundsvidenskabelige (tabel 1).

\section{Tabel 1}

\begin{tabular}{|c|c|c|c|c|c|c|}
\hline & \multicolumn{6}{|c|}{ Moduler/kurser } \\
\hline $\begin{array}{l}\text { 1. seme- } \\
\text { ster }\end{array}$ & Anatomi & Biomekanik & $\begin{array}{c}\text { Idræts- } \\
\text { pædagogik }\end{array}$ & Boldbasis & Kropsbasis & Svømning \\
\hline $\begin{array}{l}\text { 2. seme- } \\
\text { ster }\end{array}$ & \multicolumn{2}{|c|}{$\begin{array}{l}\text { Humanistisk og samfundsvi- } \\
\text { denskabelig idrætsteori }\end{array}$} & $\begin{array}{c}\text { Idrættens } \\
\text { videnskabs- } \\
\text { teori }\end{array}$ & $\begin{array}{l}\text { Menneskets } \\
\text { fysiologi }\end{array}$ & $\begin{array}{l}\text { Gymnastik og } \\
\text { bevægelses- } \\
\text { kommunikation }\end{array}$ & Atletik \\
\hline $\begin{array}{l}\text { 3. seme- } \\
\text { ster }\end{array}$ & \multicolumn{2}{|c|}{ Arbejds- og træningsfysiologi } & $\begin{array}{l}\text { Idræt og } \\
\text { sundhed }\end{array}$ & \multicolumn{2}{|c|}{ Boldspil } & Friluftsliv \\
\hline $\begin{array}{l}\text { 4. seme- } \\
\text { ster }\end{array}$ & \multicolumn{2}{|c|}{$\begin{array}{l}\text { Epidemiologi og idræts- } \\
\text { statistik }\end{array}$} & $\begin{array}{l}\text { Kvalitative } \\
\text { forsknings- } \\
\text { metoder }\end{array}$ & $\begin{array}{l}\text { Fysisk } \\
\text { træning }\end{array}$ & \multicolumn{2}{|c|}{ Undervisning og formidling } \\
\hline $\begin{array}{l}\text { 5. seme- } \\
\text { ster }\end{array}$ & \multicolumn{2}{|c|}{ Muskelfysiologi } & \multicolumn{2}{|c|}{ Præstationsoptimering } & \multicolumn{2}{|c|}{ Kultur, teori og analyse } \\
\hline $\begin{array}{l}\text { 6. seme- } \\
\text { ster }\end{array}$ & Bach & projekt & $\begin{array}{c}\text { Kost, helbred } \\
\text { og idræet }\end{array}$ & \multicolumn{3}{|c|}{ Idrætspsykologi } \\
\hline $\begin{array}{l}\text { 7. seme- } \\
\text { ster }\end{array}$ & \multicolumn{2}{|c|}{ Krop, medicin og sundhed } & \multicolumn{2}{|c|}{ Elitesport } & \multicolumn{2}{|c|}{ Kropskultur } \\
\hline $\begin{array}{l}\text { 8. seme- } \\
\text { ster }\end{array}$ & \multicolumn{2}{|c|}{ Sport og medier } & \multicolumn{2}{|c|}{ Idrætsprojekt } & \multicolumn{2}{|c|}{ Sport og etik } \\
\hline $\begin{array}{l}\text { 9. seme- } \\
\text { ster }\end{array}$ & \multicolumn{2}{|c|}{ Valgfrie kurser } & \multicolumn{4}{|c|}{ Erhvervsrettet projektforløb i idræt } \\
\hline $\begin{array}{l}\text { 10. seme- } \\
\text { ster }\end{array}$ & \multicolumn{6}{|c|}{ Speciale } \\
\hline
\end{tabular}

Tabel 1 er en illustration af idrætsuddannelsen ved Aarhus Universitet. Kurser med praktik er markeret med grønt. Kurser med færdighedstræning er markeret med blåt. 
I de første fire semestre indgår otte kurser med færdighedstræning (blå), kaldet praktisk-teoretiske fag, hvor de studerende arbejder med professionens idrætsdiscipliner som for eksempel gymnastik, boldspil og svømning, i alt 45 ECTS-points. Her tilegner de studerende sig formidlingsfærdigheder og faglig viden med henblik på at kunne arbejde med idrætsundervisning i praksis. Undervisningen ledes af studielektorer bistået af eksterne lektorer og undervisningsassistenter, der sideløbende er ansat på gymnasier eller i idrætsklubber/-organisationer. I kondenseret form er læringsmålene for disse kurser, at den studerende skal kunne: (1) indgå aktivt i det pågældende fagområde samt beherske, forevise og forstå de kropsligt-motoriske arbejdskrav og bevægelser, der gør sig gældende, og (2) planlægge, afvikle, formidle og evaluere disciplinaktiviteter og analysere didaktiske, pædagogiske, psykologiske og sociokulturelle problemstillinger.

På 4. og 9. semester indgår to kurser på henholdsvis 10 og 20 ECTS-points med praktik (grønne i tabel 1). I kurset Undervisning og formidling gennemgår de studerende et praktikforløb på 5 uger med undervisning af gymnasieelever, HF'ere eller VUC'ere. I kurset Erhvervsrettet projektforløb i idræt er de studerende i fuldtidspraktik i minimum 8 uger i en (idræts)organisation, forening/sportsklub eller virksomhed. Det primære mål med disse kurser er, at den studerende tilegner sig viden om og får erfaringer med, hvordan og på hvilket grundlag professionsudøvelse i idræt finder sted og udvikles. I begge kurser er der løbende vejledning fra den eksternt tilknyttede vejleder under praktikopholdet. 


\section{LFGEUDDANNELSEN}

Lægeuddannelsen på AU er præget af stor forskel på bachelordelen og kandidatdelen, idet kandidatdelen har udpræget fokus på praktik og færdighedstræning, mens bachelordelen har fokus på teoretiske fag (tabel 2).

Tabel 2

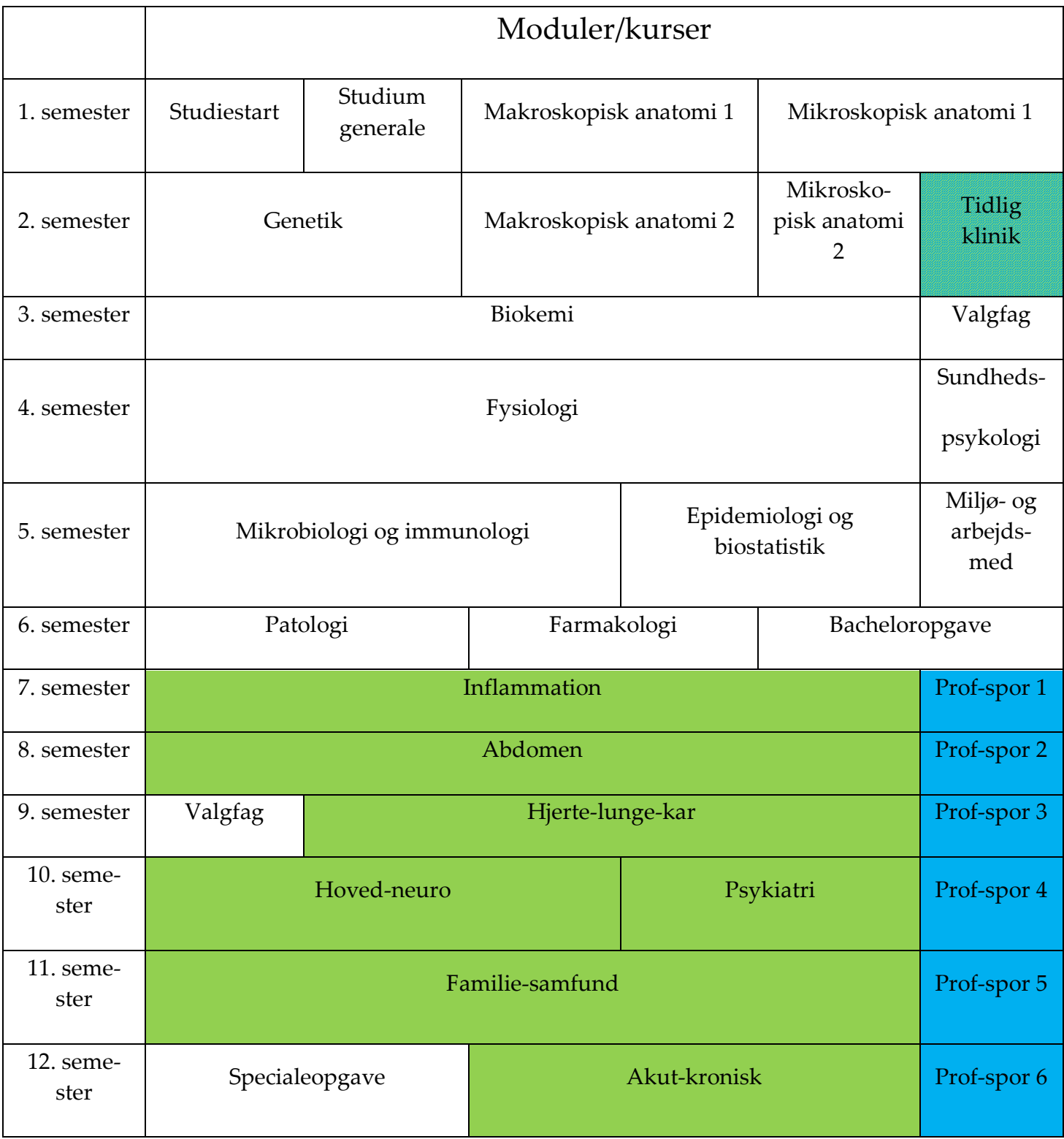

Tabel 2 er en illustration af lægeuddannelsen ved Aarhus Universitet. Kurser med praktik er markeret med grønt. Kurser med færdighedstræning er markeret med blåt.

På uddannelsens 2. semester indgår et kursus på 5 ECTS-point med både færdighedstræning og praktik ( 2 uger), kaldet Tidlig klinik. Kandidatdelen (7. - 12. semester) har derimod klar overvægt af kurser med praktik. De kurser, der baseres på færdighedstræning og simulation på kandidatdelen, kaldes professionsspor $1-6$ (blå) på hver 5 ECTS-points, i alt 30. Her tilegner de studerende sig praktiske kliniske færdigheder, som for eksempel at undersøge et knæ, kommunikative færdigheder, som for eksempel at strukturere en samtale med en patient, samt samarbejdsrelate- 
rede færdigheder, som for eksempel at lede en basal hjertestopbehandling. Derudover arbejdes der i disse kurser også med refleksion over de mere komplekse erfaringer fra praktikken, som for eksempel etiske dilemmaer. Underviserne er typisk yngre læger, der har fået et kort instruktør- eller facilitatorkursus. I kondenseret form har læringsmålene fokus på at kunne 1) rapportere og fortolke under og fra mødet med patienter, kolleger og sundhedsvæsen, 2) anvende sin viden og færdigheder til at iværksætte en række basale lægefaglige handlinger, samt 3) reflektere over egen læring og professionelle rolle.

Sideløbende hermed indgår de store kliniske kurser på hvert af kandidatdelens semester med 10 - 25 ECTS-points, i alt 130, med praktik (grønne i tabel 2). Her er de studerende i praktik på sygehuse og i almen praksis i Midt- og Nordjylland halvdelen af kursernes uger, svarende til fra 2 til 10 ugers fuldtidspraktik per semester, i alt 49 uger gennem hele studiet. De studerende indgår med egen arbejdsplan i afdelingernes daglige opgaveløsning. De superviseres og vejledes af hele afdelingen, men praktikken planlægges og koordineres af kliniske lektorer ansat på både Aarhus Universitet og sygehusene. I kondenseret form har læringsmålene fokus på at kunne 1) tale med, undersøge og omgås patienterne, 2) foreslå diagnoser (diagnostisk tænkning), 3) udarbejde og begrunde planer for udredning og behandling, samt 4) samarbejde og begå sig i det komplekse sundhedsvæsen under forandring. 


\section{SYGEPLEJERSKEUDDANNELSEN}

Sygeplejerskeuddannelsen er en professionsbacheloruddannelse. Hvert modul på sygeplejerskeuddannelsen er 10 uger, og afsluttes med en eller flere prøver (tabel 3).

Tabel 3

\begin{tabular}{|c|c|c|c|}
\hline & \multicolumn{3}{|c|}{ Moduler/kurser } \\
\hline 1. semester & $\begin{array}{c}\text { Modul } 1 \\
\text { Sygepleje - fag og profe }\end{array}$ & & $\begin{array}{c}\text { Modul } 2 \\
\text { Sygepleje - sundhed og sygdom }\end{array}$ \\
\hline 2. semester & $\begin{array}{c}\text { Modul } 3 \\
\text { Sygepleje - somatisk sygdom }\end{array}$ & lelse & $\begin{array}{l}\text { Modul } 4 \\
\text { Sygepleje - grundlæggende klinisk virksomhed }\end{array}$ \\
\hline 3. semester & $\begin{array}{l}\text { Modul } 5 \\
\text { Tværprofessionel virkso }\end{array}$ & & $\begin{array}{l}\text { Modul } 6 \\
\text { Sygepleje, kroniske syge mennesker og patienter } \\
\text { og borgere i eget hjem }\end{array}$ \\
\hline 4. semester & $\begin{array}{l}\text { Modul } 7 \\
\text { Sygepleje, relationer og inte }\end{array}$ & & $\begin{array}{l}\text { Modul 8 } \\
\begin{array}{l}\text { Sygepleje, psykisk syge patienter/borgere og } \\
\text { udsatte grupper }\end{array}\end{array}$ \\
\hline 5. semester & $\begin{array}{c}\text { Modul } 9 \\
\text { Sygepleje - etik og vidensbasere }\end{array}$ & omhed & $\begin{array}{c}\text { Modul } 10 \\
\text { Sygepleje, akut og kritisk syge patienter og } \\
\text { borgere }\end{array}$ \\
\hline 6. semester & $\begin{array}{r}\text { Modul 11 } \\
\text { Sygepleje og kompleks klinisk }\end{array}$ & mhed & $\begin{array}{l}\text { Modul } 12 \\
\text { Sygepleje og selvstændig professionsøvelse }\end{array}$ \\
\hline 7. semester & $\begin{array}{c}\text { Modul 13 } \\
\text { Valgmodul - Sygepleje, praksis-, } \\
\text { udviklings- og forskningsbaseret } \\
\text { viden }\end{array}$ & Sygep & $\begin{array}{c}\text { Modul } 14 \\
\text { eprofession - kundskabsgrundlag og metoder }\end{array}$ \\
\hline
\end{tabular}

Tabel 3 er en illustration af sygeplejerskeuddannelsen i Danmark. Kurser med praktik er markeret med grønt. Kurser med færdighedstræning er markeret med blåt.

Det er primært modulerne 1-3, 7 og 10, der indeholder elementer med færdighedstræning og simulation. Disse fem moduler er på hver 15 ECTS-point, i alt 75 (blå). Her tilegner de studerende sig kliniske færdigheder, som for eksempel pleje af stomi, sårpleje, genoplivning, samt modtagelse, observation og pleje af akutte patienter. Der er desuden fokus på teoretisk refleksion. Vejledning af de studerende varetages både af lektorer på uddannelsen og eksterne kliniske vejledere. Lektorerne har en kandidatuddannelse eller en masteruddannelse. De kliniske vejledere er uddannede syge- 
plejersker og har ofte en diplomuddannelse. Vejledning forgår forskelligt på modulerne. For eksempel kan øvelserne først demonstreres og derefter forgår vejledningen ved, at de studerende korrigeres undervejs i deres øvelser.

På 2., 3., 4. og 6. semester indgår fem moduler på 15 ECTS-point, i alt 65, med praktik elementer (grønne i tabel 3). Her er de studerende i fuldtidspraktik i 8 til 10 uger per modul svarende til i alt 46 uger gennem hele studiet. Vejledning under praktik foregår ved kliniske vejledere, der er uddannet sygeplejersker og ofte har et 6 ugers diplommodul. Nogen få har en hel diplomuddannelse. Det er meget forskelligt, hvorledes vejledningen foregår under praktik. Nogle studerende følges næsten dagligt med deres vejleder, mens andre blot snakker med deres vejleder en gang om ugen, og ellers følger en sygeplejerske i det daglige. Mange studerende går også en del alene i deres praktik. I kondenseret form er læringsmålene for de studerende i klinikperioderne, at de kan 1) identificere og handle på sygeplejebehov, 2) informere og vejlede patienter, 3) være med til at planlægge og koordinere patientforløb, samt 4) deltage i forsknings- og udviklingsprojekter.

\section{SAMMENLIGNENDE ANALYSE}

De tre uddannelser har alle færdighedstræning og praktik i kernecurriculum, men der er også betydelige forskelle (Tabel 4).

Tabel 4

\begin{tabular}{|c|c|c|c|c|}
\hline & $\begin{array}{l}\text { Princip } \\
\text { struktur }\end{array}$ & $\begin{array}{l}\text { Træning } \\
\text { indgår } \mathbf{i}\end{array}$ & $\begin{array}{l}\text { Praktik } \\
\text { indgår i }\end{array}$ & Mål for praktik \\
\hline Idræt & $\begin{array}{l}\text { Træning } \rightarrow \\
\text { Teori } \rightarrow \\
\text { Praktik } \rightarrow \\
\text { Teori }\end{array}$ & 45 ECTS & $\begin{array}{l}30 \text { ECTS } \\
\text { (13 uger) }\end{array}$ & $\begin{array}{l}\text { Anvende viden om } \\
\text { professionsudøvelsen }\end{array}$ \\
\hline Læge & $\begin{array}{l}\text { Teori } \rightarrow \\
\text { Praktik }\end{array}$ & 30 ECTS & $\begin{array}{l}130 \text { ECTS } \\
\text { (49 uger) }\end{array}$ & Indgå i professionen \\
\hline $\begin{array}{l}\text { Sygeplejer- } \\
\text { ske }\end{array}$ & $\begin{array}{l}\text { Træning } \rightarrow \\
\text { Skiftende } \rightarrow \\
\text { Praktik } \rightarrow \\
\text { Teori }\end{array}$ & 75 ECTS & $\begin{array}{l}65 \text { ECTS } \\
\text { (46 uger) }\end{array}$ & $\begin{array}{l}\text { Anvende professionens } \\
\text { viden og færdigheder }\end{array}$ \\
\hline
\end{tabular}

Tabel 4 viser et overblik over fire væsentlige, forskellige træk ved de tre uddannelser: struktur, omfanget af de kurser hvor træning og praktik indgår, samt mål. 
Idrætsuddannelsen på AU har færdighedstræning placeret på uddannelsens første semestre, fulgt af en ikkeobligatorisk praktik midt i uddannelsen, der afsluttes klassisk akademisk med specialet til slut. I modsætning hertil har lægeuddannelsen på AU de klassiske discipliner placeret på de første semestre og næsten al færdighedstræning og praktik gennemføres først sideløbende igennem hele kandidatdelen. Valgfag og speciale er kun af minimalt omfang. Sygeplejerskerne findes mellem disse to yderpunkter med færdighedstræning og praktik både tidligt og sent på uddannelsen og en afslutning med valgfag og metode.

Alle tre uddannelser lægger stor vægt på færdighedstræning, men dog i forskelligt omfang. Sygeplejerskeuddannelsen er karakteriseret ved et betydeligt fokus på færdighedstræning og i 75 af uddannelsens ECTS point er træning eller simulation elementer i undervisningen. Lægeuddannelsen har mindst fokus på færdighedstræning, dog med undervisningsformen som et bærende i element i 30 af uddannelsens ECTS point. Idræt placerer sig mellem disse to yderpunkter med 45 ECTS point.

I både læge- og sygeplejerskeuddannelserne lægges der meget stor vægt på praktik. Praktik indgår som undervisningsform i 130 af lægeuddannelsens ECTS point med et omfang på 49 praktikuger, og i sygeplejerskeuddannelsen i 65 ECTS point med et omfang på 46 praktikuger. Idræt har med 30 ECTS point mindst indbygget praktik i et omfang på 13 praktikuger.

Fokus i læringsmålene for færdighedstræningen har en række ligheder. Målene fokuserer primært på 1) konkrete fagspecifikke praktiske færdigheder (for eksempel at svømme en bestemt stilart, at undersøge et knæ eller observere en akut patient), 2) læringsmål inden for samarbejde, kommunikation og formidling, samt 3) mål der relaterer sig til planlægnings- og handlekompetence. På læge- og sygeplejerskeuddannelserne indgår desuden komplekse, refleksive mål om etik, rolle og læring i færdighedstræningen.

Målene for praktik varierer mere mellem de tre uddannelser. Det primære mål for praktik på idræt er, at den studerende tilegner sig viden om og får erfaringer med, hvordan og på hvilket grundlag professionsudøvelse i idræt finder sted og udvikles. Både læge- og sygeplejerskestuderende forventes derimod at indgå i de autentiske opgaver og skal derfor kunne varetage konkrete patientrelaterede opgaver som leder til udredning, pleje, patientinformation og behandling $i$ et komplekst samarbejde med den arbejdende sygehusafdeling.

Underviserkorpsene adskiller sig også på de tre uddannelser, men har dog en række ligheder. På læge- og sygeplejerskeuddannelsen varetages færdighedstræning primært af eksterne lektorer og yngre praktikere. På idrætsuddannelsen varetages færdighedstræningen derimod af fuldtidsansatte studieadjunkter. 
Alle tre uddannelser bruger eksternt tilknyttede vejledere på de involverede arbejdspladser i den daglige vejledning. På lægeuddannelsen er praktikforløbene dog ret detaljeret planlagt og ledes af eksterne lektorer.

\section{Diskussion}

På de tre uddannelser er der foretaget forskellige, didaktiske valg i forbindelse med placering og omfang af praktik og færdighedstræning. Vi foreslår, at disse valg både afspejler professionsidentiteterne og påvirker de studerendes professionelle identitet som beskrevet af Heggen (2008). I lægeuddannelsen, hvor der traditionelt set er en stærk professionsidentitet, og de studerende allerede under studiet forventes at udvikle en professionel identitet, udgør praktikperioder med tæt kontakt til professionsudøverne en meget væsentlig del af kandidatuddannelsen. Fortolkning og refleksion indgår eksplicit i læringsmålene og fokus ligger på at 'træde ind' i det autentiske arbejde. Dette fokus på 'at indgå i professionen' er så overraskende stærkt, at færdighedstræningen ganske vist er inkluderet, men slet ikke i samme omfang som på hverken idræt eller sygeplejeuddannelsen. I modsætning hertil har idrætsuddannelsen, med en betydelig mindre grad af udtrykt professionsidentitet, mere færdighedstræning end praktikforløb. Samtidig ligger fokus i både praktik og træning på tilegnelse af viden, hvilket smukt afspejler en professionsidentitet som 'idrætsakademiker'. Endelig var det et interessant fund, at sygeplejerskeuddannelsen vægter færdighedstræning så højt. Dette didaktiske valg kunne være udtryk for en helt tredje forståelse af disse undervisningsformers betydning for sygeplejerskestuderendes udvikling af professionel identitet, hvor beherskelse af færdigheder har stor betydning.

Analysen peger således i retning af en forskellig vægtning i de tre uddannelser mellem videnskabelig funderet teoretisk viden, praktisk ekspertise og etisk-social forpligtigelse (se figur 1), selvom alle tre elementer indgår i tankegangen og idealforståelsen på alle tre uddannelser. En forsigtig konklusion kunne - også for diskussionens skyld - placere de tre uddannelser med vægtning i hver sit hjørne. Idræt har gennem hele uddannelsen - også i kurser med træning og praktik - fokus på videnskabelig funderet, teoretisk viden samt på anvendelsen heraf i praksis. Det virker som om, lægeuddannelsen skifter ringhjørne, så bacheloruddannelsens overvejende fokus på videnskabelig funderet teoretisk viden er underforstået i kandidatuddannelsen, der derfor fokuserer på lægerollens særligt etisk-sociale forpligtigelser i det lægelige praksisfællesskab. Endelig kunne man konkludere, at sygeplejeuddannelsen aktuelt har et betydeligt fokus på praktisk ekspertise og færdigheder gennem hele uddannelsen. 
Dette studie er begrænset til desk research baseret på tre cases fra videregående sundhedsfaglige uddannelser i Region Midt og konklusionerne kan derfor naturligvis ikke generaliseres i absolut forstand. Vi antager, at de tre cases er repræsentative for danske videregående sundhedsfaglige uddannelser. Uden for den kontekst kan konklusionerne ikke udstrækkes langt ud over en forhåbentlig tankevækkende sammenligning, og studiet kunne derfor med fordel suppleres med cases fra helt andre typer videregående uddannelser. Dog vil vi mene, at forbindelsen mellem professionsidentitet, professionel identitetsudvikling og uddannelsens didaktiske valg, hvad angår praktik og færdighedstræning, må kunne genfindes i andre cases.

Når de videregående uddannelser responderer på de politiske opfordringer til at øge omfanget af praktikforløb, så bør det følges af en betydelig forskningsindsats. Man ved, at praktik muliggør sociale, udviklende, autentiske læringsaktiviteter, at praktik udvikler studerendes professionelle identitet og, at praktik forbereder til arbejdslivet. Men der er også mange udestående spørgsmål. Med dette studie har vi vist, at praktikperioderne kan struktureres vidt forskelligt. Hvad forestiller studerende og undervisere sig om betydningen af færdighedstræning og praktik for læring og professionel udvikling? Hvilke muligheder åbner færdighedstræning og praktik for læring og professionel udvikling på videregående uddannelser og hvordan?

\section{Konklusion}

Både færdighedstræning og praktik vægtes højt på idræts-, læge- og sygeplejerskeuddannelserne, men med betydelige variationer. Vi kan ikke pege på om professionsidentitetsforståelsen i de tre 'professioner' er årsag eller virkning, men et samspil ser der ud til at være. Praktikforløbene kan både placeres midt i (sygeplejerske og idræt) eller i slutningen (læge) af uddannelsen. Balancen mellem træning og praktik kan variere fra omkring 1:1 (sygeplejerske og idræt) til 1:5 (læge). Endelig har målene for praktikken væsensforskelligt fokus. Der er dermed ikke én skabelon for praktik, og vi opfordrer til mere forskning i praktik på videregående uddannelser i Danmark.

Anne Mette Mørcke er lektor i sundhedsvidenskabelig fagdidaktik ved Center for Medicinsk Uddannelse, Aarhus Universitet. AMM er uddannet læge og har siden 1999 beskxftiget sig med udvikling af og forskning i lxgeuddannelsen med interesse for studiereformer og planlægning, kernecurriculum, outcome-based education, undervisningsformer, færdighedstræning, arbejdspladsbaseret læring og vejledning, refleksion og professionalisme, proveformer samt årsager til frafald. AMM underviser i og rådgiver om sundhedsvidenskabelig fagdidaktik på alle niveauer fra studenterundervisere til undervisningsansvarlige på Health, Aarhus Universitet.

Kristian Raun Thomsen er studielektor og leder af den praktisk-teoretiske udviklingsenhed på Sektion for Idræt, Aarhus Universitet. KRT er cand.mag. i Pædagogik og cand.scient. i Idræt. KRT er tidligere elitefodboldspiller og har siden 2001 været ansat som seminarielærer, højskolelærer, fysisk træner og idrætskonsulent. KRT er kursusansvarlig underviser i bl.a. boldspil, idrætspædagogik, undervisning og formidling samt erhvervsrettet projektforløb $i$ idræt. Udover artikelbidrag til en antologi om uddannelsesforskning er KRT i gang med et forskningsprojekt om ekspertise og fodboldtalent. 
Jette Henriksen er lektor og programleder for Program for Innovation og Forskning i Uddannelse ved Sundhedsfaglig Højskole, VIA University College. JH er uddannet sygeplejerske og har siden 1994 beskxftiget sig med udvikling og uddannelse af sygeplejersker. JH's forskningsinteresser ligger inden for læring af sygepleje i færdighedslaboratorier og studieunits og hun har specialiseret sig i etnografiske studier af disse. Desuden interesserer JH sig for uddannelsesvalg og karrieredrømme hos studerende ved sundhedsfaglige uddannelser. JH underviser på sygeplejerskeuddannelsen primært i forskningsmetodologi.

Ole Lund er ph.d. i idræt og ansat som postdoc ved Center for Medicinsk Uddannelse, Aarhus Universitet, hvor han studerer udviklingen af talentfuld og professionel adfærd blandt universitetsstuderende. I sin ph.d.-afhandling studerede OL mesterlærerelationer blandt danske eliteidratsudøvere. OL's forskningsinteresser ligger inden for mesterlære, elitepræstationer, ekspertise, laring $i$ sociale praksisser samt de ekspressive og sansede dimensioner af læring og ekspertise.

Mette Krogh Christensen er lektor og forskningsleder på Center for Medicinsk Uddannelse, Aarhus Universitet, hvor hendes interesse og forskningsområde er samspillet mellem uddannelsesmiljø og faglig udvikling inden for de sundhedsvidenskabelige uddannelser. MKC har specialiseret sig $i$ kvalitative studier af kulturelle og læringsmæssige aspekter af talentudvikling og talentudviklingsmiljøer inden for elitesport og forskeruddannelse. Som underviser arbejder MKC med en række universitetspæedagogiske emner (herunder vejledning og team-based learning) $i$ forbindelse med underviserudvikling på bl.a. adjunktpædagogikum.

\section{Litteratur}

Bleakley, A. \& Brennan N. (2011). Does undergraduate curriculum design make a difference to readiness to practice as a junior doctor? Medical Teacher, 33, s. 459467.

Broek, S. D. \& Hake, B. J. (2012). Increasing participation of adults in higher education: Factors for successful policies. International Journal of Lifelong Education, 31(4), s. 397-417.

Chambers, F. C. \& Armour, K. M. (2011). Do as we do and not as we say: teacher educators supporting student teachers to learn on teaching practice. Sport, Education and Society 16(4), s. 527-544.

Christensen, M. K. (2001). Når alderen indhenter én: Kropslighed, aldring og profession hos gymnasiets idrætslærere. Ph.d. afhandling. København: Institut for Idræt, Københavns Universitet.

Heggen, K. (2008). Profession og identitet. I: Molander, A. \& Terum, L. I. (red.): Profesjonsstudier. Oslo: Universitetsforlaget.

Kilminster S., Zukas, M., Quinton, N. \& Roberts, T.(2011). Preparedness is not enough: understanding transitions as critically intensive learning periods. Medical Education 45(10), s. 1006-1015.

Løvold, E. (1996). Styrker de pasientorienterte praksisstudiene sykepleierstudentenes sykepleiefaglige identitet? En beskrivende studie om sykepleierstudenters bevisstgjøring av sykepleiefaglig identitet i utdanningens praksisstudier. Oslo: Universitetet i Oslo. Nielsen, C., Stenholt, B., Lomborg, K. \& Bjørk, I. T. (2013). Praktiske færdigheder i professionsrettede sundhedsuddannelser. Dansk Universitetspædagogisk Tidsskrift 8(15), s. 60-73.

Politiko (2012): http://www.b.dk/politiko/morten-oestergaard-flere-studerende-skal- 
i-praktik.

Skok, M. M. \& Dolinšek, T. (2013). Some findings on career counseling in higher education. Journal of Enterprising Communities 7(1), s. 81-94.

Standal, Ø. F. \& Moe, V. F. (2013). Reflective practice in physical education and physical education teacher education: a review of the literature since 1995. Quest 65(2), s. 220-240.

Teunissen, P. \& Wilkinson, T. (2011). Learning and teaching in workplaces. In: Dornan, T. , Mann, K. V., Scherpbier, A. J. J. A. \& Spencer, J. A. (Eds). Medical education - theory and practice. Edinburgh: Elsevier.

Van der Zwet, J., Zwietering, P. J., Teunissen, P. W., van der Veluten, C. P. M. \& Scherpier, A. J. J. A., (2011). Workplace learning from a socio-cultural perspective: creating developmental space during the general practice clerkship. Advances in Health Sciences Education 16(3), s. 359-373. 